\title{
ISSUES OF ANALYTICAL DESIGN OF LAND DIVISION WITH HIGH VALUE PER HECTARE
}

\author{
Mariusz Zygmunt, Marek Ślusarski, Jacek Gniadek, Robert Szewczyk
}

\begin{abstract}
Summary
The article discusses the problem of analytical design of a plot for a given value, in the cases where estimates occur in land division with high point values. Accordingly, it becomes problematic to meet the expected results of valuable design, preserved during the conduct of design work for estimated outline of "average" values. Provisions regarding technical standards for performing geodetic situational measurements determine the necessity of rounding the coordinates of boundary points to $1 \mathrm{~cm}$. Maintaining the designed value with an accuracy down to 1 point generates problems linked with the compatibility between the expected value and the one obtained. Generating the report after the merger introduces unavoidable changes, and must be taken into account when conducting the consolidation work.
\end{abstract}

\section{Keywords}

land consolidation $\bullet$ value of parcels $\bullet$ value design

\section{Introduction}

The problem of value design has been known for decades [Banat et al. 1989, Żak 2006]. Due to the specificity of this type of work, the estimated boundaries expressing the value of the land had to be based on the actual value; the latter most often having its source mainly in the land classification, but also taking into account other factors (such as for instance location or terrain). The absolute values for the majority of consolidation objects ranged between 0 and 300 points per 1 hectare $(0$ for excluded lands). The values of individual plots or farms were recorded with the accuracy down to 1 point. Reconstruction of the designed equivalent was also carried out with an accuracy of 1 point. This approach was easy to understand for everyone, particularly for the participants in mergers. The value of the land presented in the registry before the consolidation was the basis for conducting design works, and designating the equivalent for the participants in accordance with the applicable regulations. 
This was also reflected in the course of designing work, in information systems. The final result was consistent with the projected one, designed with the accuracy down to 0.01 point. The final result was not affected by the final rounding of the coordinates of the newly designed parcel boundaries up to $1 \mathrm{~cm}$. Such requirements are currently imposed by applicable legal acts [Rozporządzenie 2011]. Designing works carried out at present usually include coordinates of points with a greater level of accuracy. This actually depends on the IT system used to support the designing work. The currently used MKSCAL software [Janus and Zygmunt 2016, Jagielski and Marczewska 2011], aimed at supporting the designing work, takes into account the method of subsequent approximations [Zygmunt 2010]. Due to the universality of its application in practice, the research was carried out using the said system. This allowed us to carry out a detailed analysis of the obtained design results, and perform an estimation of the impact of the applicable guidelines in the field of surveying performance on the accuracy of designing plots in areas with a high value of estimated boundaries. It should be noted that the selection of a system applied to the performance of designing work is not significant in this case. Instead, we focus only on the interpretation of results from the obtained works.

\section{Material and methods}

Due to the analogy to the linear metre method, using state-of-the-art information technology, we can talk about the linear centimetre method. For example, for an area of 100 points and the size of 1 hectare (measuring $100 \times 100$ metres), the value of the 1 -metre wide strip is 1 point. Design with the accuracy of coordinates of up to $1 \mathrm{~cm}$ can be carried out with an accuracy of 0.01 points. The question arises as to how to approach the problem of valuable design for estimated boundaries described with values many times greater than those adopted and used most often?

For a more complete presentation of the problem, we will use an example of estimated boundaries for forest divisions. Figure 1 shows a fragment of the consolidation area with very large fragmentation of forest-covered land plots. The approximate model of estimated complexes has been developed on the basis of the data published by the General Directorate of State Forests, on the website of the industry geoportal and the database of general geographic objects and cadastral data (Fig. 2).

For the object we study, the value of 1 hectare varies between 1000 and 50,000 points (Fig. 3).

Corresponding areas for the assumed design complexes and their values are presented in Table 1. The information contained therein shows that the values of complexes K-03, $\mathrm{K}-04$, and $\mathrm{K}-05$ are around 1000 times greater than those adopted using the scoring base according to on other guidelines. For instance, in the consolidation instruction no. 1 a complex is given: $25-€-1 \mathrm{~V}-40$, with a value of one hectare $=40$ points.

It is a common practice to design plots within the limits of acceptable deviation of $3 \%$ of the value between the initial and newly designed state. The reasons for this may be different (for instance, discrepancies between the map and the register, result- 
ing from the way the land registry survey is carried out). If we take into account this correction in the work that we conduct, then we must be aware that the final result may differ by more than the acceptable $3 \%$.

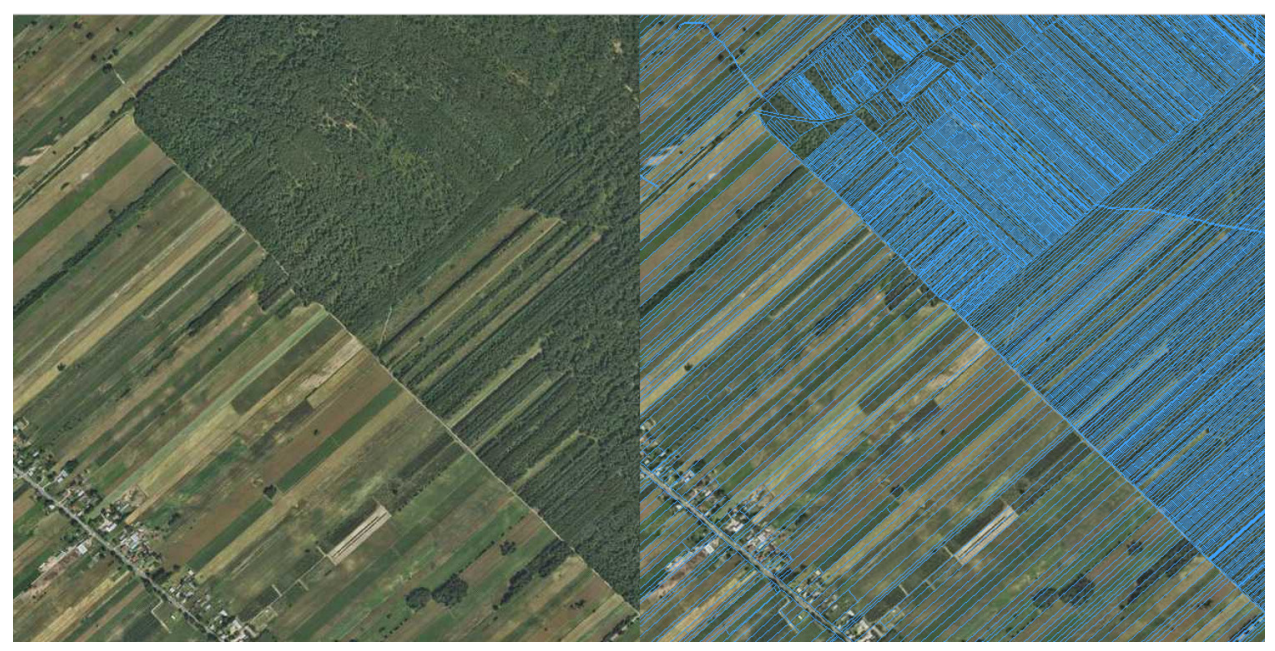

Source: thematic geoportal

Fig. 1. A sample object of consolidation. Image on the left: ortophotomap; image on the right: ortophotomap with plotted land register data



Source: thematic geoportal

Fig. 2. A sample object of consolidation. Image on the left: data from the visualisation of the Database of General Geographic Object; image on the right: ortophotomap with plotted data elaborated by the General Directorate of State Forests 


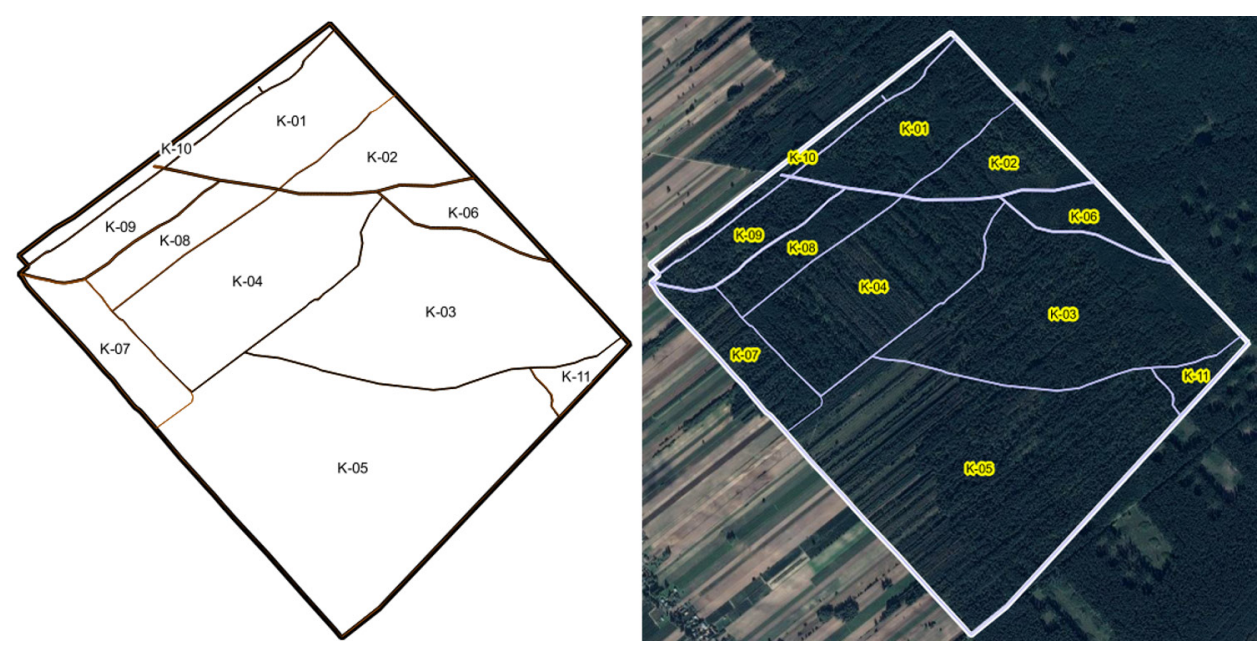

Source: own study using the orthophotomap background

Fig. 3. Estimate complexes with marked roads

Table 1. Actual surfaces of design complexes and their values

\begin{tabular}{|c|c|c|}
\hline No. of complex & Surface area [ha] & Value [points] \\
\hline K-01 & 3269.6890 & 638413.0554 \\
K-02 & 1998.6516 & 432504.9509 \\
K-03 & 14350.7239 & 1609528.7109 \\
K-04 & 6034.4548 & 1009146.4167 \\
K-05 & 1543.6357 & 2325616.1311 \\
K-06 & 2430.6517 & 259392.7096 \\
K-07 & 345.1535 & 319137.6506 \\
K-08 & 3086.8358 & 416691.9431 \\
K-09 & 10012.3682 & 370568.6824 \\
K-10 & 12757.8128 & 246198.3804 \\
K-11 & 3176.9957 & 116395.5177 \\
\hline
\end{tabular}

Source: own study

\section{Results and discussion}

The comparative test of the theoretical (expected) and final values was carried out on 45 designed plots (Fig. 4). For research purposes, three values of planned plots were assumed: 100,000, 250,000 and 500,000 points. The directions of the design lines were selected taking into account the natural external boundaries of the test object. The results are presented in a tabular form, listing the number of the designed plot, its practical (actual) and theoretical (designed) surface area, and relative error, expressed in [\%] (Table 2). 


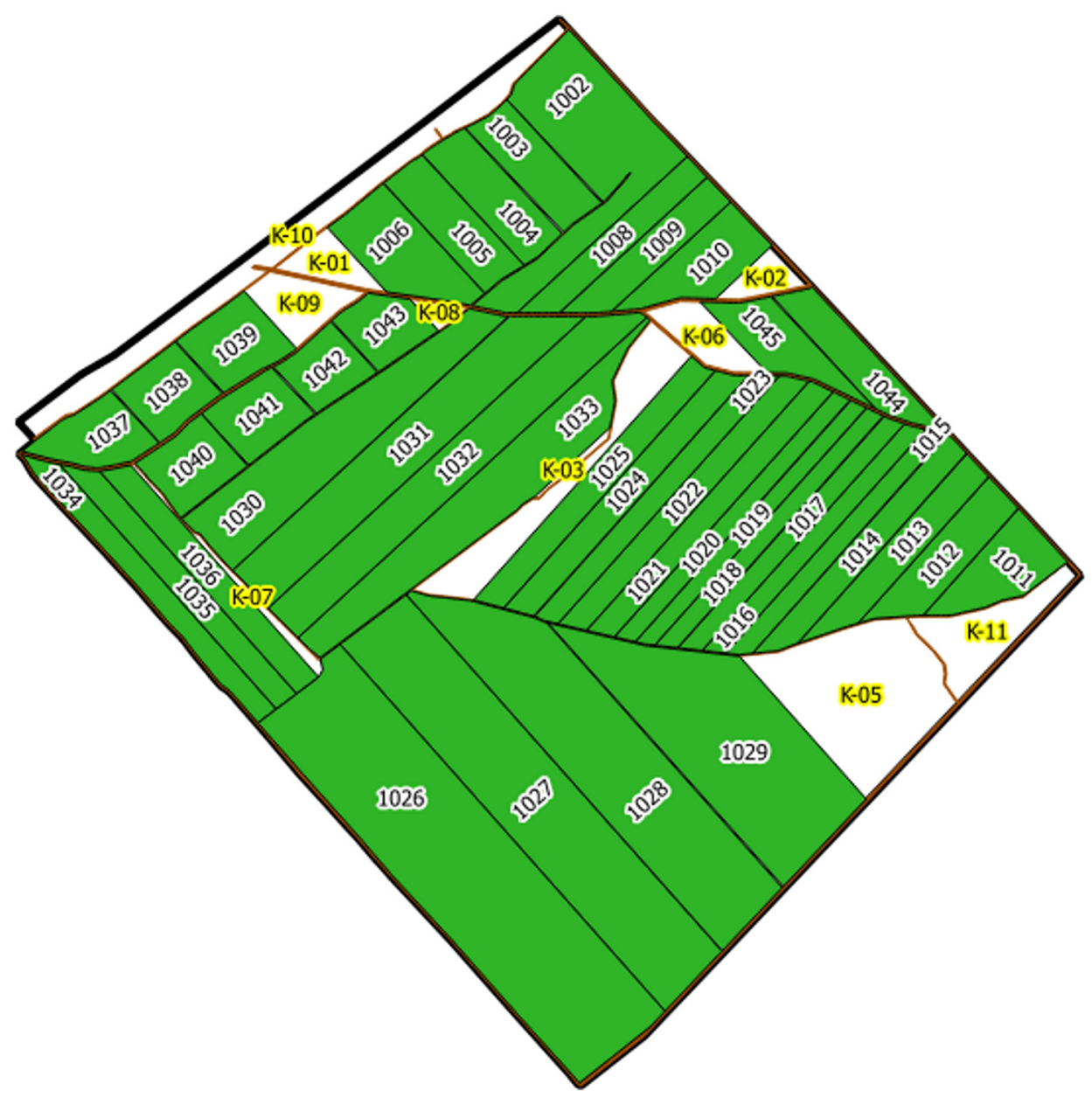

Fig. 4. Designed plots within design complexes (with sample values of 100,000, 250,000 and 500,000 points)

Table 2. Values of relative error for the designed plots

\begin{tabular}{|c|c|c|c|c|c|c|c|c|c|}
\hline No. & $\begin{array}{c}\text { Surface } \\
\text { area } \\
{[\text { ha] }}\end{array}$ & $\begin{array}{c}\text { Value } \\
\text { [points] }\end{array}$ & $\begin{array}{c}\text { Theo- } \\
\text { retical } \\
\text { value }\end{array}$ & $\begin{array}{c}\text { Relative } \\
\text { error } \\
{[\%]}\end{array}$ & No. & $\begin{array}{c}\text { Surface } \\
\text { area } \\
{[\text { ha] }}\end{array}$ & $\begin{array}{c}\text { Value } \\
\text { [points] }\end{array}$ & $\begin{array}{c}\text { Theo- } \\
\text { retical } \\
\text { value }\end{array}$ & $\begin{array}{c}\text { Relative } \\
\text { error } \\
{[\%]}\end{array}$ \\
\hline 1001 & 960.7485 & 99998.57 & 100000 & 0.001 & 1024 & 522.1306 & 99998.97 & 100000 & 0.001 \\
\hline 1002 & 2336.305 & 100002.27 & 100000 & 0.002 & 1025 & 9035.492 & 99999.80 & 100000 & 0.000 \\
\hline 1003 & 177.6254 & 99997.76 & 100000 & 0.002 & 1026 & 1353.961 & 500008.42 & 500000 & 0.002 \\
\hline 1004 & 1061.153 & 99996.91 & 100000 & 0.003 & 1027 & 189.6744 & 500007.83 & 500000 & 0.002 \\
\hline 1005 & 3269.689 & 99998.67 & 100000 & 0.001 & 1028 & 1500.678 & 499999.92 & 500000 & 0.000 \\
\hline
\end{tabular}


Table 2. cont.

\begin{tabular}{|c|c|c|c|c|c|c|c|c|c|}
\hline No. & $\begin{array}{c}\text { Surface } \\
\text { area } \\
\text { [ha] }\end{array}$ & $\begin{array}{c}\text { Value } \\
\text { [points }]\end{array}$ & $\begin{array}{c}\text { Theo- } \\
\text { retical } \\
\text { value }\end{array}$ & $\begin{array}{c}\text { Relative } \\
\text { error } \\
{[\%]}\end{array}$ & No. & $\begin{array}{c}\text { Surface } \\
\text { area } \\
\text { [ha] }\end{array}$ & $\begin{array}{c}\text { Value } \\
\text { [points] }\end{array}$ & $\begin{array}{c}\text { Theo- } \\
\text { retical } \\
\text { value }\end{array}$ & $\begin{array}{c}\text { Relative } \\
\text { error } \\
{[\%]}\end{array}$ \\
\hline 1006 & 3153.188 & 100000.94 & 100000 & 0.001 & 1029 & 3907.268 & 499997.04 & 500000 & 0.001 \\
\hline 1007 & 1068.652 & 100004.50 & 100000 & 0.005 & 1030 & 292.8193 & 250003.46 & 250000 & 0.001 \\
\hline 1008 & 929.9998 & 99998.05 & 100000 & 0.002 & 1031 & 590.9551 & 249994.33 & 250000 & 0.002 \\
\hline 1009 & 1155.614 & 99999.52 & 100000 & 0.000 & 1032 & 518.6446 & 249996.04 & 250000 & 0.002 \\
\hline 1010 & 4266.666 & 99999.43 & 100000 & 0.001 & 1033 & 5515.81 & 249996.40 & 250000 & 0.001 \\
\hline 1011 & 5162.684 & 100001.18 & 100000 & 0.001 & 1034 & 10063.76 & 100001.41 & 100000 & 0.001 \\
\hline 1012 & 1958.957 & 99996.78 & 100000 & 0.003 & 1035 & 6034.677 & 100007.69 & 100000 & 0.008 \\
\hline 1013 & 569.4873 & 99995.98 & 100000 & 0.004 & 1036 & 82.9282 & 99998.46 & 100000 & 0.002 \\
\hline 1014 & 6276.885 & 100003.07 & 100000 & 0.003 & 1037 & 10012.37 & 99998.60 & 100000 & 0.001 \\
\hline 1015 & 174.3529 & 100002.04 & 100000 & 0.002 & 1038 & 1968.094 & 99999.64 & 100000 & 0.000 \\
\hline 1016 & 1496.19 & 99991.42 & 100000 & 0.009 & 1039 & 2278.534 & 99999.69 & 100000 & 0.000 \\
\hline 1017 & 3494.4 & 99996.41 & 100000 & 0.004 & 1040 & 3086.836 & 99998.91 & 100000 & 0.001 \\
\hline 1018 & 3185.202 & 99998.86 & 100000 & 0.001 & 1041 & 16304.22 & 100002.07 & 100000 & 0.002 \\
\hline 1019 & 851.2425 & 100009.97 & 100000 & 0.010 & 1042 & 25202.43 & 99998.22 & 100000 & 0.002 \\
\hline 1020 & 2000.78 & 100006.10 & 100000 & 0.006 & 1043 & 25203.03 & 100000.58 & 100000 & 0.001 \\
\hline 1021 & 16886.45 & 100002.99 & 100000 & 0.003 & 1044 & 269.831 & 100004.63 & 100000 & 0.005 \\
\hline 1022 & 14539.09 & 99997.58 & 100000 & 0.002 & 1045 & 2430.652 & 100000.12 & 100000 & 0.000 \\
\hline 1023 & 664.9297 & 99998.05 & 100000 & 0.002 & & & & & \\
\hline
\end{tabular}

Source: own study

\section{Conclusions}

Due to the increasing use of high value for the description of estimated boundaries, one should remember about the consequences resulting from their use in the design process. The authors used real data in the preparation of the present paper. The relative error value is very small, in practice not exceeding $0.01 \%$. However, one should remember about the practical dimension of the issue in question. Having modern IT solutions at our disposal, we must be aware of the consequences resulting from the accuracy imposed by the instructions in relation to the real-life situation. Recording the coordinates of boundary points with accuracy down to one centimetre results in inevitable consequences when developing results based on such accuracy. The most important one is the impossibility to ensure the actual design of plots with the accuracy down to one point. Awareness of this fact is often lacking, even among those who carry out design work. 


\section{References}

Banat J., Przegon W., Sanek A., Schilbach J. 1989. Metody geodezyjnego projektowania działek w urządzaniu obszarów wiejskich. Akademia Rolnicza w Krakowie, Kraków.

Geoportal branżowy, http://mapy.geoportal.gov.pl/imap/?gpmap=gp1 [accessed: 01.08.2018]. Instrukcja nr 1 Ministra Rolnictwa i Gospodarki Żywnościowej o scalaniu i wymianie gruntów z dnia 24 marca 1983 r. Gz-G-630-1/83. Warszawa.

Jagielski A., Marczewska B. 2011. Geodezja w gospodarce nieruchomościami, chapter: Zygmunt M., Janus J. MKScal - system kompleksowej obsługi scaleń gruntów, vol. 3, 136-150.

Janus J., Zygmunt M. 2016. MKScal-system for land consolidation project based on CAD platform. Geomatics, Landmanagement and Landscape, 2, 49-59.

Rozporządzenie Ministra Rozwoju Regionalnego i Budownictwa w sprawie ewidencji gruntów i budynków z dnia 29 marca 2001 r. (Dz. U. z 2016 r., poz. 1034).

Rozporządzenie Ministra Spraw Wewnętrznych i Administracji w sprawie standardów technicznych wykonywania geodezyjnych pomiarów sytuacyjnych i wysokościowych oraz opracowania i przekazywania wyników tych pomiarów do państwowego zasobu geodezyjnego i kartograficznego z dnia 9 listopada 2011 r. (Dz. U. Nr 263, poz. 1572).

Ustawa z dnia 26 marca 1982 r. o scalaniu i wymianie gruntów (Dz. U. z 2018 r., poz. 908).

Ustawa z dnia 28 września 1991 r. o lasach (Dz. U. z 2017 r., poz. 788 z późn. zm.).

Zygmunt M. 2010. Projektowanie działek metodą iteracyjną. Infrastruktura i ekologia terenów wiejskich, 3, 89-94.

Żak M. 2006. Geodezyjne Urządzanie Terenów Rolnych. Kraków.

http://www.codgik.gov.pl/index.php/zasob/baza-danych-ogolnogeograficznych.html [accessed: 01.08.2018].

https://www.geoportal.gov.pl/web/guest/DOCHK [accessed: 01.08.2018].

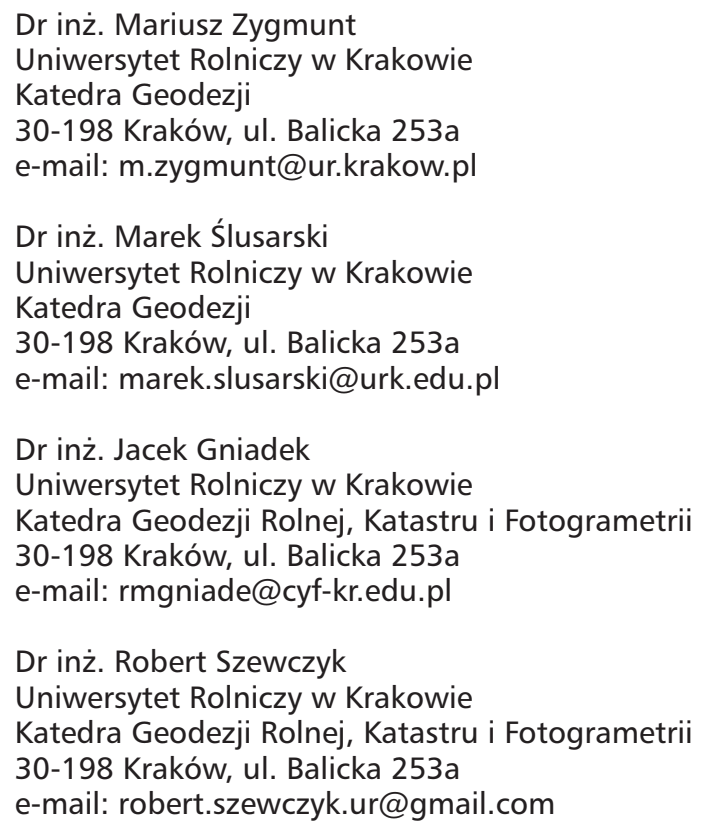

